\title{
HEPATOPROTECTIVE EFFECT OF PERILLYL ALCOHOL (POH) ON HIGH-FAT DIET-LOW-DOSE STREPTOZOTOCIN-INDUCED TYPE 2 DIABETES IN EXPERIMENTAL RATS
}

\author{
TOWSEEF HASSAN*, ELANCHEZHIYAN C, INSHA NASEER
}

Department of Zoology, Annamalai University, Chidambaram, Tamil Nadu India. Email: esstowseefhassan@gmail.com

Received: 28 April 2019, Revised and Accepted: 25 May 2019

\begin{abstract}
Objective: The aim of the present study was to investigate the hepatoprotectivity effect of perillyl alcohol in high-fat diet (HFD)-low-dose streptozotocin (STZ)-induced diabetic rats.

Methods: Diabetes was induced in male albino Wistar rats by 4 weeks diet manipulation followed by a low single intraperitoneal injection of STZ ( $35 \mathrm{mg} / \mathrm{kg}$ body weight). Perillyl alcohol was administered orally (50 mg/kg body weight and $100 \mathrm{mg} / \mathrm{kg}$ body weight) for $30 \mathrm{days}$. Glibenclamide was used as a standard drug and given orally $6 \mathrm{mg} / \mathrm{kg}$ body weight. At the end of treatment period, levels of alkaline phosphatase (ALP), aspartate transaminase (AST) alanine transaminase (ALT), and bilirubin and serum protein were measured in serum of experimental rats. Histopathological studies of liver were also done with microscope.
\end{abstract}

Results: The levels of ALP, AST ALT, and bilirubin were increased significantly in HFD-STZ-induced diabetic rats. Perillyl alcohol-treated diabetic rats showed marked restoration in the activity of ALP, AST, ALT, and bilirubin when compared with diabetic control rats. Perillyl alcohol and glibenclamide drug-treated rats showed reversible tissue regeneration with prominent hepatocytes.

Conclusion: The present results clearly indicate that the perillyl alcohol has a potent efficacy for hepatoprotective effect in HFD- low-dose STZ-induced diabetic rats.

Keywords: High-fat diet, Streptozotocin, Perillyl alcohol, Glibenclamide, Bilirubin.

(C) 2019 The Authors. Published by Innovare Academic Sciences Pvt Ltd. This is an open access article under the CC BY license (http://creativecommons. org/licenses/by/4. 0/) DOI: http://dx.doi.org/10.22159/ajpcr.2019.v12i7.33797

\section{INTRODUCTION}

Diabetes mellitus (DM) is characterized by hyperglycemia, means high blood glucose levels disturbances in carbohydrate, protein and fat metabolism, and is a widespread metabolic disease almost found in all countries [1]. DM the metabolic disorder is caused by hereditary (or) acquired shortage in insulin secretion and by decreased sensitivity of the organs to secrete insulin [2]. The number of adults with diabetes in the world is predictable to increase from 135 million in 1995 to 300 million in the year of 2025 [3]. Elevated levels of glucose in blood cause oxidative stress as a result of increased creation of mitochondrial reactive oxygen species (ROS), nonenzymatic glycation of proteins, and glucose autoxidation [4]. Glycosylation of hemoglobin and lipid peroxidation are important parameters that help in the progression of complications of diabetes in patients [5]. Liver helps to store the body excess glucose as glycogen by this process liver plays an important role in glucose homeostasis [6]. When oxidative stress increases in liver, the liver cells are affected so the important thing is to protect the liver to maintain the normal metabolic activity. When diabetes is not treated, it will lead to so many problems such as eye problem, neuropathy, kidney disease, aging, liver problems, and other complications [7]. Synthetic antidiabetic drugs have so many side effects [8], and many traditional plants decrease glucose levels and have no side effect at all [9]. Therefore, recently proper hypoglycemic agents have been focused in traditional medicine because some natural products in traditional medicine may be better treatments than currently used drugs [10]. Perillyl alcohol (POH) (Fig. 1) is a naturally occurring monocyclic monoterpene that can be purified from various plants such as peppermint, spearmint, cherries, and celery [11]. It has been shown by the researchers that $\mathrm{POH}$ possesses considerable antitumor, anticancer, anti-inflammatory, and antifungal activity $[12,13]$.

In view of the above medicinal properties, the present study was designed to investigate the hepatoprotective activity of perillyl alcohol in high-fat diet (HFD)-STZ-induced diabetic rats.

\section{METHODS}

Animals

Healthy male albino Wistar rats (160-180 g) were obtained from Biogen Laboratory Animal Facility, Bengaluru, India, and maintained at a constant temperature $\left(25 \pm 1^{\circ} \mathrm{C}\right)$ on a $12 \mathrm{~h}$ light $/ 12 \mathrm{~h}$ dark cycle with standard pellet diet (National Institute for Nutrition, Hyderabad, India) and water was provided ad libitum. The study was approved by the Institutional Animal Ethics Committee of Rajah Muthiah Medical College (Reg. no. 160/PO/ReBi/S/1999/CPCSEA, Proposal no. 1192), Annamalai University.

\section{Chemicals}

Perillyl alcohol (POH) and streptozotocin (STZ) were purchased from Sigma-Aldrich (St. Louis, MO, USA), and other chemicals were obtained from E. Merck, Himedia (Mumbai India). All of the chemicals and reagents used in these experiments were analytical grade.

\section{HFD-fed STZ-induced diabetes}

The rats were divided into two dietary regimens by feeding either normal or HFD for the initial period of 4 weeks [14]. The composition (Table 1) and preparation of HFD (58\% fat, $25 \%$ protein, and $17 \%$ carbohydrate, as a percentage of total kcal) have been described earlier [15]. After

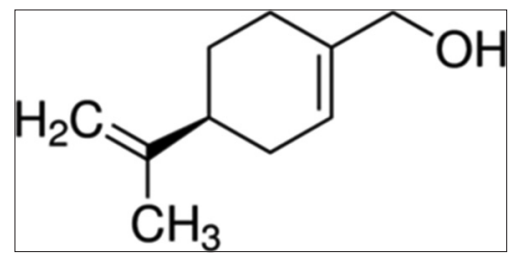

Fig. 1: Structure of perillyl alcohol $\left(\mathrm{C}_{10} \mathrm{H}_{16} \mathrm{O}\right)$ 
4 weeks of dietary manipulation, the groups of rats fed with HFD were injected intraperitoneally with a low dose of STZ (35 mg/kg b.w.) dissolved in 0.1M cold citrate buffer, $\mathrm{pH} 4.5$ ). 3 days after STZ injection, the rats were screened for blood glucose level. Rats having fasting blood glucose $>250 \mathrm{mg} / \mathrm{dl}$ that exhibited random hyperglycemia and glycosuria were selected for the experiment. The rats were allowed to continue to feed on the respective diets until the end of the experiments.

\section{Experimental design}

A total number of 30 rats were divided into 5 groups of six animals each ( 6 normal rats and 24 diabetic rats). Saline was used as vehicle. Perillyl alcohol and glibenclamide were dissolved in saline and administered orally once in a day for 30 days.

- Group 1 - Normal rats treated with vehicle alone

- Group 2 - HFD-fed STZ-induced experimental diabetic rats (35 mg/kg b.w.)

- Group 3 - HFD-fed STZ-induced diabetic rats orally treated with perillyl alcohol ( $50 \mathrm{mg} / \mathrm{kg}$ b.w./day for 30 days)

- Group 4 - HFD-fed STZ-induced diabetic rats orally treated with perillyl alcohol $(100 \mathrm{mg} / \mathrm{kg}$ b.w./day for 30 days)

- Group 5 - HFD-fed STZ-induced diabetic rats orally treated with glibenclamide ( $6 \mathrm{mg} / \mathrm{kg}$ b.w./day for 30 days).

During the experimental period, body weight, food and water consumption, and physical examinations were determined at regular intervals. At the end of the treatment period, the rats were fasted overnight and sacrificed by cervical decapitation. The blood was collected with and without anticoagulants for plasma and serum separation, respectively.

\section{Histopathological studies}

The liver tissue was fixed in $10 \%$ formalin for $48 \mathrm{~h}$. It was then followed by dehydration by passing through a series of graded alcohol, beginning with $50 \%$ alcohol and progressing in graded step to $100 \%$ (absolute) alcohol and was finally embedded in paraffin. Sections of the liver (5-6 $\mu \mathrm{m}$ thick) were developed using semi-automated rotator microtome, stained with hematoxylin and eosin dye, and observed microscopically [16].

\section{Biochemical analysis}

Alanine transaminase (ALT), aspartate transaminase (AST), and alkaline phosphatase (ALP) were assayed in serum using commercial kits obtained from Sigma Diagnostics (I) Pvt., Ltd., Baroda, India.

Table 1: Composition of high-fat diet

\begin{tabular}{ll}
\hline Ingredients & Diet (g/100 g) \\
\hline Powdered NPD & 36.5 \\
Lard & 31 \\
Casein & 25 \\
Cholesterol & 1 \\
Sodium cholate & 0.5 \\
Vitamin mineral mix & 6 \\
dl-methionine & 0.3 \\
Yeast powder & 0.1 \\
Sodium chloride & 0.1 \\
\hline
\end{tabular}

*The composition of NPD: $4.1 \%$ fat, $22.2 \%$ protein, and $12.1 \%$ carbohydrates, as a percentage of total kilocal. NPD: Normal pellet diet
Total serum protein was estimated using the method of Lowry et al., 1951 [17]. Serum bilirubin was estimated by the method of Malloy and Evelyn 1937 [18].

\section{Statistical analysis}

All values are expressed as mean \pm standard deviation for six rats in each group. One-way ANOVA followed by Tukey's multiple comparison tests using IBM SPSS version 22. Statistical significance was compared within the groups as follows: ${ }^{a}$ Control rats and bdiabetic control rats. Values are statistically significant at $* \mathrm{p}<0.05$

\section{RESULTS}

Effect of perillyl alcohol on AST, ALP, ALT, and serum bilirubin In the present study, the hepatoprotective markers in serum of HFDlow-dose STZ-induced diabetic rats ALT, AST, ALP (Table 2 and Fig. 2), and serum bilirubin (Table 2 and Fig. 3 ) level were increased in diabetic group when compared with normal group and treated with perillyl alcohol 50 and $100 \mathrm{mg} / \mathrm{kg}$ body weight significantly decrease these markers.

\section{Effect of perillyl alcohol on liver weight}

Liver weight was consistently decreased in diabetic group (Fig. 4) and when treated with perillyl alcohol, 50 and $100 \mathrm{mg} / \mathrm{kg}$ b.w., liver weight increased when compared with diabetic group (Table 2).

\section{Effect of perillyl alcohol on total serum protein}

Fig. 5 depicts the changes in serum total protein in control and diabetic rats, serum protein significantly decrease in diabetic control group $(\mathrm{p}<0.05)$, and when the rats were treated with perillyl alcohol, 50 and $100 \mathrm{mg} / \mathrm{kg}$ b.w., the serum total protein significantly increased near to the normal when compared with diabetic control group.

\section{Histological observations}

The liver of treated diabetic rats with $\mathrm{POH} 50$ and $100 \mathrm{mg} / \mathrm{kg}$ body weight showed significant results. Normal control rats show ideal hepatocytes in liver tissue (Fig. 6a), and diabetic control rats show tissue damage in liver hepatocytes and major blood sinusoids and internal blood cysts (Fig. 6b). Perillyl alcohol and glibenclamide drugtreated rats showed reversible tissue regeneration with prominent hepatocytes (Fig. 6c-e).

\section{DISCUSSION}

Presently available drug regimens in the market for the management of DM have certain side effects so there is a need to find safer and more effective antidiabetic drugs with no or very less side effects especially from plant origin [19]. For the successful therapeutic strategies, we need to have interaction between the oral hypoglycemic drugs and the phytochemicals in terms of bioavailability, metabolism, and steadiness [20]. The present study was meant to determine the efficiency of perillyl alcohol on hepatoprotective activity of normal and HFD-STZinduced diabetic rats. HFD is now a day used by researchers to induce the insulin resistance which is the main cause of type 2 diabetes HFD also induces obesity it in turn increases oxidative stress [21]. To induce the experimental diabetes, STZ is commonly used it causes the selective $\beta$-cell cytotoxicity through the release of nitric oxide. This results in speedy decrease in pancreatic islet pyridine nucleotide concentration

Table 2: Effect of perillyl alcohol on hepatoprotective markers Serum Bilirubin, ALT, AST, ALP and liver weight in diabetic animals treated with perillyl alcohol

\begin{tabular}{|c|c|c|c|c|c|}
\hline Groups & Liver weight (g) & Serum bilirubin (mg/dl) & $\operatorname{ALP}(I U / L)$ & AST (IU/L) & ALT (IU/L) \\
\hline Normal control & $6.79 \pm 0.52$ & $0.64 \pm 0.15$ & $75.44 \pm 5.36$ & $49.08 \pm 3.46$ & $21.09 \pm 2.23$ \\
\hline Diabetic control (HFD-STZ) & $4.85 \pm 0.71^{\mathrm{a}, *}$ & $1.14 \pm 0.08^{\mathrm{a}, *}$ & $130.32 \pm 8.39^{a, *}$ & $78.23 \pm 3.98^{\mathrm{a}, *}$ & $31.75 \pm 3.11^{\mathrm{a}, *}$ \\
\hline D+POH (50 mg/kg b.w) & $6.00 \pm 0.35^{\mathrm{b}, *}$ & $0.88 \pm 0.23^{b}$ & $90.85 \pm 3.94^{\mathrm{b}, *}$ & $60.08 \pm 3.46^{\mathrm{b}, *}$ & $25.13 \pm 2.34^{\mathrm{b}, *}$ \\
\hline $\mathrm{D}+\mathrm{POH}(100 \mathrm{mg} / \mathrm{kg} \mathrm{b} . \mathrm{w})$ & $6.23 \pm 0.31^{\mathrm{b}, *}$ & $0.77 \pm 0.20^{\mathrm{b}, *}$ & $81.32 \pm 5.34^{\mathrm{b}, *}$ & $55.08 \pm 3.63^{\mathrm{b}, *}$ & $24.05 \pm 2.12^{\mathrm{b}, *}$ \\
\hline $\mathrm{D}+\mathrm{GC}(6 \mathrm{mg} / \mathrm{kg}$ b.w. $)$ & $6.66 \pm 0.69^{\mathrm{b}, *}$ & $0.73 \pm 0.10^{\mathrm{b}, *}$ & $80.07 \pm 5.62^{\mathrm{b}, *}$ & $52.08 \pm 6.14^{\mathrm{b}, *}$ & $22.88 \pm 2.34^{\mathrm{b}, *}$ \\
\hline
\end{tabular}

All values are expressed as mean \pm SD for six rats in each group. One-way ANOVA followed by Tukey's multiple comparison tests. Statistical significance was compared within the groups as follows: a Control rats and 'Diabetic control rats. Values are statistically significant at *p<0.05. ALP: Alkaline phosphatase, AST: Aspartate transaminase, ALT: Alanine transaminase, SD: Standard deviation, HFD: High-fat diet, STZ: Streptozotocin 


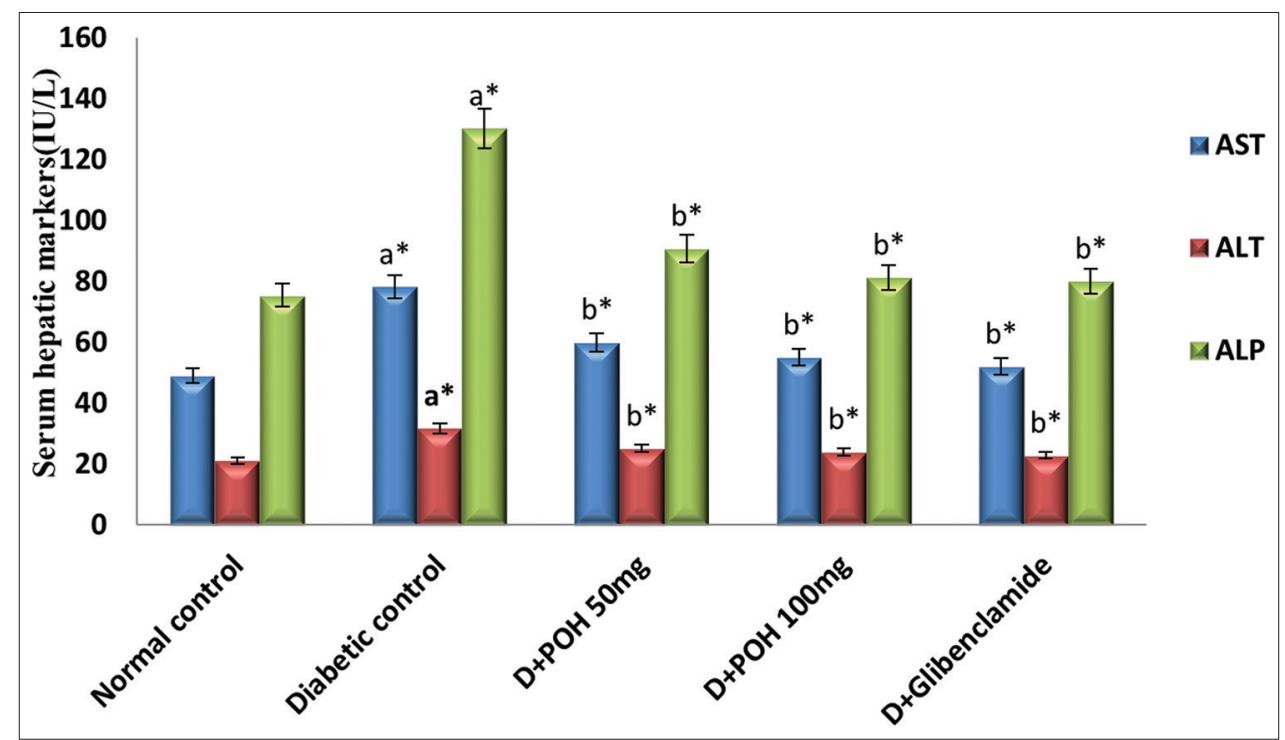

Fig. 2: Effect of perillyl alcohol on hepatic markers on high-fat diet-low-dose streptozotocin-induced diabetic rats. One-way ANOVA followed by Tukey's multiple comparison tests statistical significance was compared within the groups as follows: aControl rats and ${ }^{b}$ diabetic control rats. Values are statistically significant at * $\mathbf{p}<0.05$

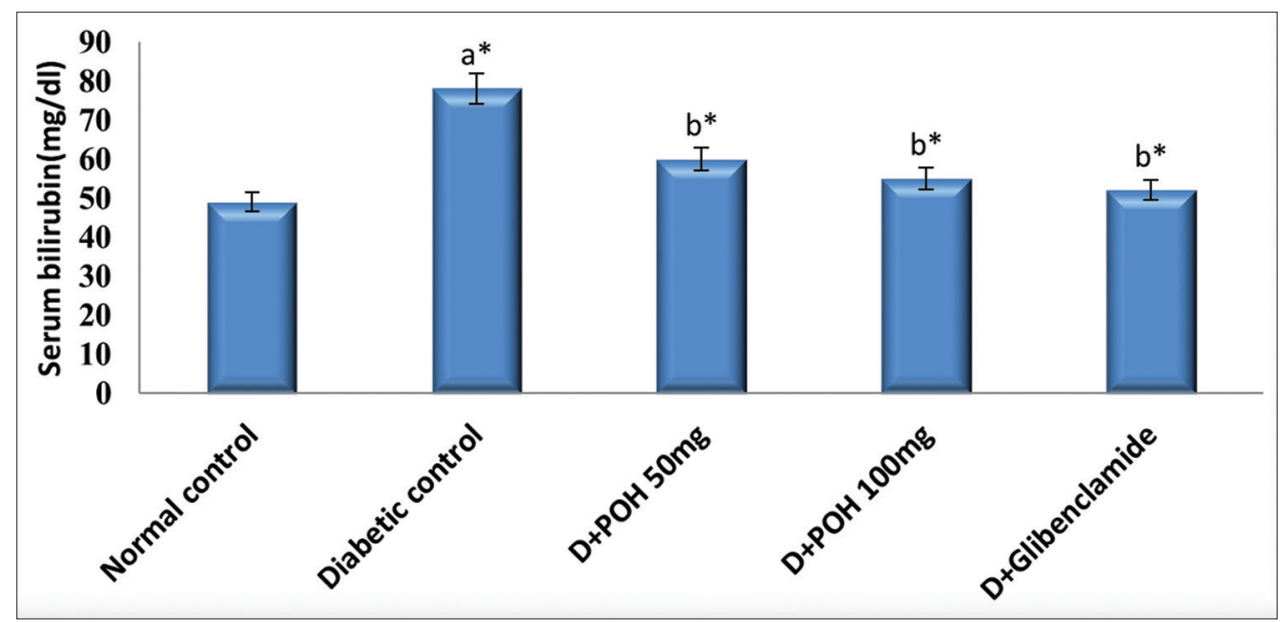

Fig. 3: Effect of perillyl alcohol on bilirubin on high-fat diet-low-dose streptozotocin-induced diabetic rats. One-way ANOVA followed by Tukey's multiple comparison tests statistical significance was compared within the groups as follows: ${ }^{\mathrm{a}}$ Control rats and ${ }^{\mathrm{b}}$ diabetic control rats. Values are statistically significant at ${ }^{*} \mathbf{p}<0.05$

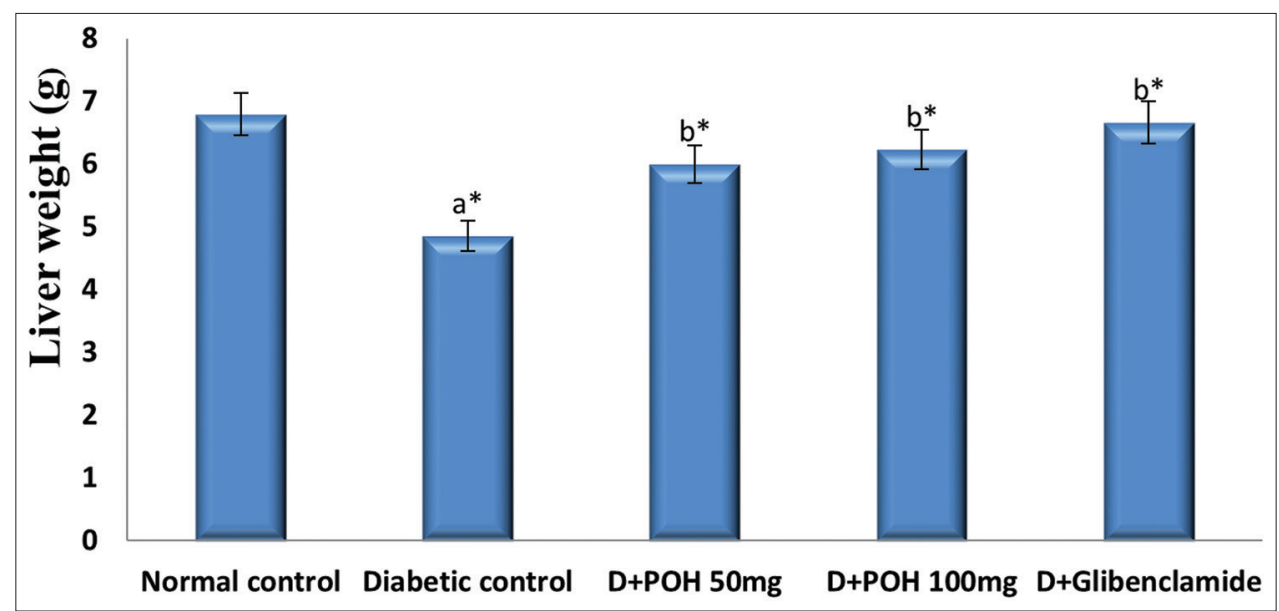

Fig. 4: Effect of perillyl alcohol on liver weight of high-fat diet-low-dose streptozotocin-induced diabetic rats. One-way ANOVA followed by

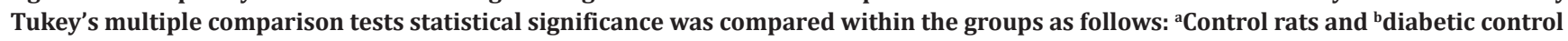
rats. Values are statistically significant at ${ }^{*} \mathbf{p}<0.05$ 


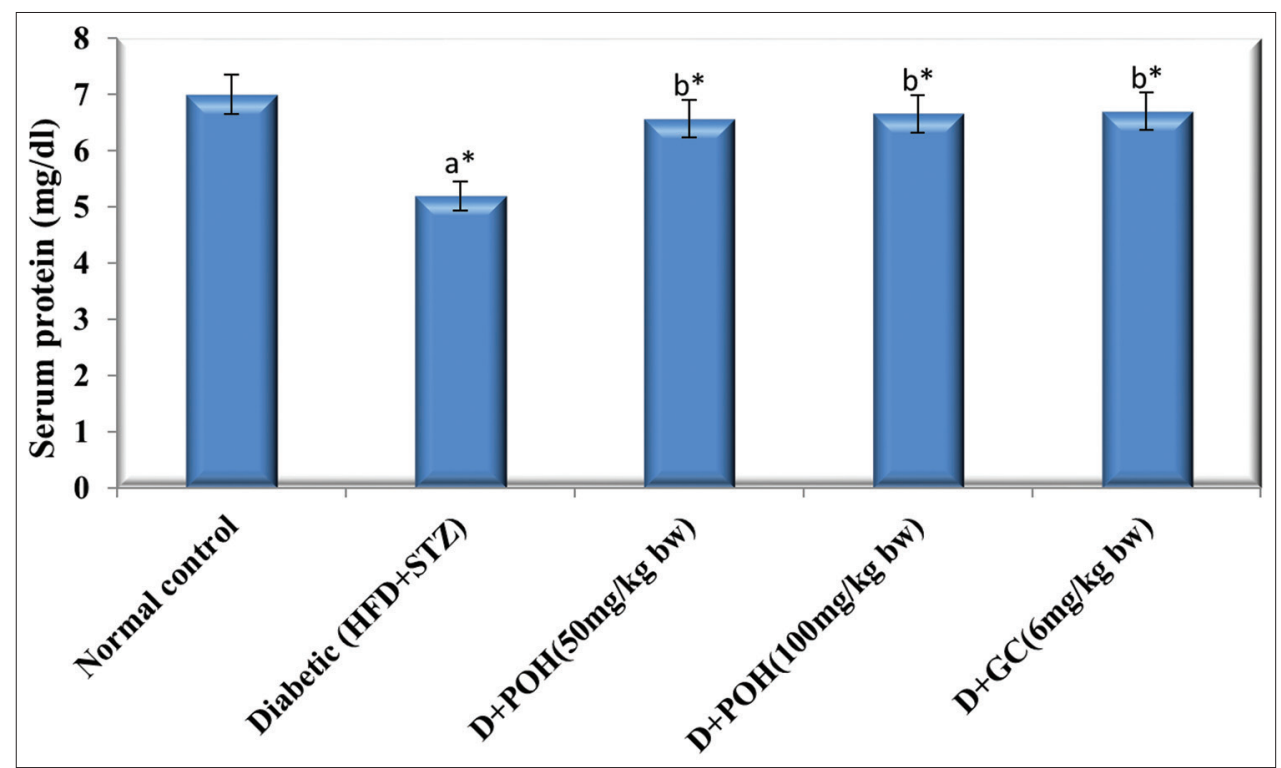

Fig. 5: Effect of perillyl alcohol on serum total protein on high-fat diet- low-dose streptozotocin-induced diabetic rats. One-way ANOVA

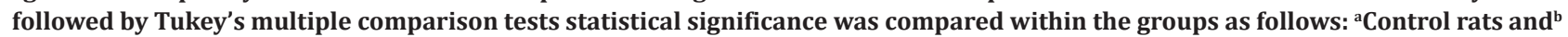
diabetic control rats. Values are statistically significant at $* \mathrm{p}<0.05$

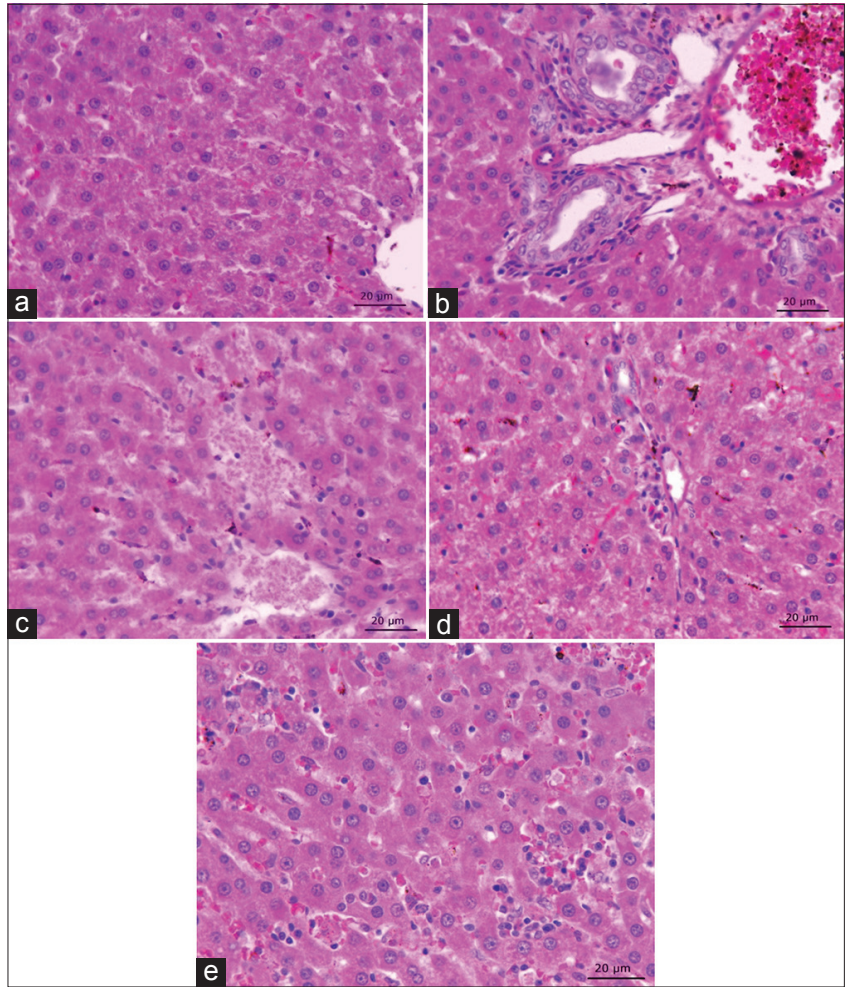

Fig. 6: (a-e) Histological observation of liver of normal and high-fat diet (HFD)-low-dose streptozotocin (STZ)-induced diabetic rats. Histopathological observations of perillyl alcohol and glibenclamide-treated liver in HFD-STZ-induced diabetic rats after 30 days of treatment (H\&E staining, ×40). (a) Normal control - normal histological structure of hepatic, hepatic cords, hepatic sinusoids, and central vein. (b) Diabetic control - mild sinusoids damaged hepatocytes were observed. (c) Diabetic + POH $50 \mathrm{mg} / \mathrm{kg} \mathrm{b.w.,} \mathrm{(d)} \mathrm{diabetic} \mathrm{+} \mathrm{POH} 100 \mathrm{mg} / \mathrm{kg} \mathrm{b.w.),} \mathrm{and}$ (e) diabetic + glibenclamide $6 \mathrm{mg} / \mathrm{kg}$ b.w. - showed reversible tissue regeneration and prominent hepatocytes

and following $\beta$-cell necrosis. The act of STZ on mitochondria generates SOD anion, which leads to diabetic complications [22-24]. In the present investigation, HFD/STZ is used to induce diabetic condition in male Wistar rats. Standard antidiabetic drug glibenclamide is used to compare the antihyperglycemic activity in experimental rats. The glibenclamide is a standard antidiabetic drug, used to compare the antihyperglycemic property in experimental rats [25]. In the present study, HFD-STZ-administered rats showed increased levels of plasma glucose and decreased insulin levels. The oral administration of perillyl alcohol to diabetic rats showed the levels of plasma glucose reduced and insulin levels increase toward near normalcy when results were compared with diabetic untreated group. Perillyl alcohol by its ability reverses the hepatoprotective markers to near normal level. The normal ability of liver to synthesis glycogen is impaired in diabetes; there is the problem with the enzymes. Synthase phosphatase not activates glycogen synthase to glycogenesis [26]. Necrosis cause decreased in the cell mass that is, why the liver weight is decreased in diabetes [27]. The diabetic rats treated with perillyl alcohol at the dose of 50 and $100 \mathrm{mg} / \mathrm{kg}$ body weight maintained the liver weight near to normal levels. From our investigation, it is well clear that POH prevents the glycation of proteins in the liver and serum. AST, ALT, and ALP are reliable markers of liver function $[28,29]$. An increase in the activities of AST, ALT, and ALP in serum might be mainly due to the leakage of these enzymes from the liver cytosol into the bloodstream which gives an indication of the hepatotoxic effect of STZ [30]. Treatment of the diabetic rats with perillyl alcohol reduced the activity of these enzymes in serum compared to the diabetic untreated group and consequently alleviated liver damage caused by HFD-lowdose STZ-induced diabetes. This study also supports the possibility of regeneration of tissues even the damage is severe as we found in the liver of experimental rats [31]. Significant reductions in the activities of these enzymes increase in liver weight regeneration of liver tissue damage in $\mathrm{POH}$-treated diabetic rats indicated the hepatoprotective role in preventing diabetic complications.

\section{CONCLUSION}

Perillyl alcohol restored the altered serum enzymes (AST, ALT, and ALP) and bilirubin. And also, histopathological studies of tissues confirmed the recovery of tissue damage. The action of perillyl alcohol was comparable to the antidiabetic drug glibenclamide. Results of this experimental study indicated that perillyl alcohol possessed hepatoprotective activities. Further pharmacological and biochemical investigations are underway to explain the mechanism of the antidiabetic effect of perillyl alcohol. 


\section{ACKNOWLEDGMENT}

All the authors would like to thank the Department of Zoology, Annamalai University Annamalai Nagar, Tamil Nadu, India, for providing all facilities for this work.

\section{AUTHORS' CONTRIBUTIONS}

Towseef Hassan and Insha Naseer, Ph.D. Research Scholars performed the experimental work, prepared the data, and drafted the write-up. C. Elanchezhiyan, Associate Professor, Department of Zoology guided the research work and edited the write-up.

\section{CONFLICTS OF INTEREST}

There is no conflict of interest.

\section{REFERENCES}

1. American Diabetes Association. Diagnosis and classification of diabetes mellitus. Diabetes Care 2011;34:562-569.

2. Matsui T, Tanaka T, Tamura S, Toshima A, Tamaya K, Miyata Y, et al. Alpha-glucosidase inhibitory profile of catechins and theaflavins. J Agric Food Chem 2007;55:99-105.

3. Liu H, Liu X, Jia L, Liu Y, Yang H, Wang G, et al. Insulin therapy restores impaired function and expression of P-glycoprotein in blood-brain barrier of experimental diabetes. Biochem Pharmacol 2008;75:1649-1658.

4. Dewanfee S, Das AK, Sahu R, Gangopadhyay M. Antidiabetic activity of diaspyros pregrim fruit effect on hyperglycemia, hyperlipidemia and augmented oxidative stress in experimental Types 2 diabetes. Food Chem Toxicol 2004; 47:2679-2685.

5. Latha M, Pari L. Effect of an aqueous extract of Scoparia dulcis on blood glucose, plasma insulin and some polyol pathway enzymes in experimental rat diabetes. Braz J Med Biol Res 2004;37:577-586.

6. Lavoie JM, Bergeron R, Latour MG. Regulatory impact of intrahepatic carbohydrate and lipid metabolism. Can J Appl Physiol 2005;30:282-291.

7. Sabu MC, Kuttan R. Anti-diabetic activity of medicinal plants and its relationship with their antioxidant property. J Ethnopharmacol 2002;81:155-160.

8. Arafat M, Salam A, Arafat O. The association of Type 2 diabetes with obesity and other factors: In multinational community. Int J Pharm Pharm Sci 2014;6:257-260.

9. Noor SA, Gunasekaran A, Manickam S, Vijayalakshmi VA. Anti diabetic activity of Aloe vera and histology of organs in streptozotocin induced diabetic rats. Curr Sci 2008;94:1070-1075.

10. Rates SM. Plants as source of drugs. Toxicon 2001;39:603-13.

11. Belanger JT. Perillyl alcohol: Applications in oncology. Altern Med Rev 1998;3:448-457.

12. Ansari MA, Fatima Z, Hameed S. Anticandidal effect and mechanisms of monoterpenoid, perillyl alcohol against Candida albicans. PLoS One 2016;11:e0162465.

13. Bailey HH, Attia S, Love RR, Fass T, Chappell R, Tutsch K, et al. Phase II trial of daily oral perillyl alcohol (NSC 641066) in treatmentrefractory metastatic breast cancer. Cancer Chemother Pharmacol 2008;62:149-157.

14. Magdalena JS, Flaczyk E, Jeszka J, Krejpcio Z, Król E, Buchowski MS.
Mulberry leaf extract intake reduces hyperglycaemia in streptozotocin (STZ)-induced diabetic rats fed high-fat diet. J Funct Foods 2014;8:9-17. 15. Veerapur VP, Prabhakar KR, Kandadi MR, Srinivasan KK, Unnikrishnan MK. Antidiabetic effect of Dodonaea viscosa aerial parts in high fat diet and low dose streptozotocin-induced Type 2 diabetic rats: A mechanistic approach. Pharm Biol 2010;48:1137-1148.

16. Luna LG. Manual of Histologic Staining Methods of the Armed Forces Institute of Pathology. $3^{\text {rd }}$ ed. New York: Blakiston Division, McGraw-Hill; 1968.

17. Lowry OH, Rosebrough NJ, Farr AL, Randall RJ. Protein measurement with the folin phenol reagent. J Biol Chem 1951;193:265-275

18. Malloy HT, Evelyn KA. The determination of bilirubin with the photoelectric colorimeter. J Biol Chem 1937;119:481.

19. King KJ, Armstrong AL. Calcium, phosphorus and phosphatase. In: Varley H, editor. Practical Clinical Bio Chemistry. $4^{\text {th }}$ ed. New Delhi: CBS Publishers; 1988

20. Panchal I, Sen DJ, Navle A, Shah U. Structure-based drug designing, scoring, and synthesis of some substituted sulphonylureas/guanidinebased derivatives as hypoglycemic agents. Int J Pharm Pharm Sci 2017;9:226-232

21. Hassan T, Elanchezhiyan C, Naseer I, Veerakumar D. Protective effect of perillyl alcohol (POH) a monoterpene: On high fat diet induced hyperlipidemia in albino Wistar rats a preliminary study. Int J Pharm Sci Res 2019;10:1000-1004.

22. Reitman S, Frankel S. A colorimetric method for the determination of serum glutamic oxalacetic and glutamic pyruvic transaminases. Am J Clin Pathol 1957;28:56-63.

23. Segen JC. Liver function tests. In: Concise Dictionary of Modern Medicine. New York: MC Graw-Hill Companies; 2002.

24. Bandyopadhyay P. Advances in the understanding of diabetes mellitus. Drug News Perspect 2004;17:477-487.

25. Papaccio G, Pisanti FA, Latronico MV, Ammendola E, Galdieri M. Multiple low-dose and single high-dose treatments with streptozotocin do not generate nitric oxide. J Cell Biochem 2000;77:82-91.

26. Anderson T, Schein PS, McMenamin MG, Cooney DA. Streptozotocin diabetes correlation with extent of depression of pancreatic islet nicotinamide adenine dinucleotide. J Clin Invest 1974;52:672-677.

27. Szkudelski T. The mechanism of alloxan and streptozotocin action in B cells of the rat pancreas. Physiol Res 2001;50:537-546.

28. Alarcon-Aguilara FJ, Roman-Ramos R, Perez-Gutierrez S, Aguilar-Contreras A, Contreras-Weber CC, Flores-Saenz JL, et al. Study of the anti-hyperglycemic effect of plants used as antidiabetics. J Ethnopharmacol 1998;61:101-110.

29. Saputri FC, Astari C, Janatry DA, Azizahwati A, Kusmana D. Hepatoprotective effect of Bellamya javanica: Aspartate transaminase, alanine aminotransferase, and alkaline phosphatase activity, and liver histopathology in mice induced with carbon tetrachloride. Int J Appl Pharm 2018;10:203-207.

30. Grover JK, Vats V, Yadav S. Effect of feeding aqueous extract of Pterocarpus marsupium on glycogen content of tissues and the key enzymes of carbohydrate metabolism. Mol Cell Biochem 2002;241:53-59.

31. Srividya G, Adilaxmamma K, Srilatha CH. Protective effect of Acorus calamus rhizome in paracetamol exposure induced hepatotoxicity in rats: Biochemical and histopathological study. Int J Curr Pharm Res 2018;10:7-10. 